\title{
PHYTOSTEROLS IN HUMAN HEALTH: FRIENDS OR FOES?
}

\section{FITOESTEROLES EN LA SALUD HUMANA: ¿AMIGOS O ENEMIGOS?}

(iD Jorge L. Gutierrez-Pajares ${ }^{1}$ (iD) Funing $M A^{2}$

${ }^{1}$ Faculty of Food Sciences. Le Cordon Bleu University, Lima, Peru.

${ }^{2}$ Haikou Experimental Station, Chinese Academy of Tropical Agricultural Sciences/Hainan Key Laboratory for Biosafety Monitoring and Molecular Breeding in Off-Season Reproduction Regions, Haikou, Hainan 571101, China

Correspondencia:

Dr. Jorge Gutiérrez Parajes

jorge.gutierrez@ulcb.edu.pe

\section{ABSTRACT}

Phytosterols are steroids present in photosynthetic organisms and are frequent molecules present in the human diet. There is evidence showing the consumption of phytosterols can prevent cardiovascular problems, mainly by decreasing blood absorption of cholesterol present in our diet. In addition, there are research results pointing to an anticancer effect of PS. However, as presented in this article, recommendations to increase phytosterol consumption should be followed with precaution and medical guidance.

\section{RESUMEN}

Fitoesteroles son esteroides presentes en organismos fotosintéticos y son moléculas presentes frecuentemente en la dieta humana. Hay evidencia que señala que el consumo de fitoesteroles puede prevenir problemas cardiovasculares, principalmente disminuyendo la absorción del colesterol presente en nuestra dieta. Además, se han encontrado estudios que indican que los fitoesteroles tienen un efecto anticancerígeno. No obstante, la recomendación de incrementar la ingesta de fitoesteroles debería tomarse con cautela y bajo seguimiento médico puesto que se han reportado efectos adversos. 


\section{PHYTOSTEROLS, WHAT ARE THEY?}

Both plant sterols and stanols are plant steroid molecules with a similar structure and function to cholesterol in humans that are collectively known as phytosterols (PS). The common structure among plant and animal sterols is a cyclopentanoperhydrophenanthrene ring. Additional biochemical modifications have been described for plant sterols and stanols compared to cholesterol. Thus, an additional ethyl and methyl group are found in $\beta$-sitosterol/ stigmasterol and campesterol at C-24 of their sterol side chain, respectively. Besides, plant stanols do not present insaturated bonds while plant sterols do.

In plants, functions of PS within the plant cell occur in a similar way as cholesterol in animal cells (Clouse, 2002), such as being part of the cell membrane and as substrates for elaboration of hormones. Metabolism in each part of a plant influences the relative amount of PS and key enzymes that are involved in PS biosynthesis have been identified (Zhang et al., 2020). In addition to normal physiology, infection of plants can modify their sterol contents. Thus, the infection of tomato (Solanum lycopersicum) with the root-knot nematode Meloidogyne incognita changes the $\beta$-sitosterol-to-stigmasterol ratio significantly (Cabianca et al., 2021).

In summary, PS are functional molecules in plants that are regulated by their metabolism and in response to biotic and abiotic factors. This may influence the specific content of a particular PS in the plant or part of the plant consumed in a diet.

\section{DISTRIBUTION IN MICROORGANISMS, ALGAE AND PLANTS}

Due to their chemical structure, plant sterols and stanols are present in the insaponificable part of plant fats and are highly concentrated in plant oils. PS co-exist in plants along with cholesterol as part of cell structure and metabolism, while PS are not synthesized in animal cells (Sonawane et al., 2016). Also, in some cases, high levels of cholesterol have been found in plants, like in Perilla frutescens (Oh et al., 2021).

PS are principally found in wheat germs, vegetable oils, nuts, and seeds. Among PS, $\beta$-sitosterol, campesterol and stigmasterol are the most common sterols present in the human diet. Plant stanols are less abundant in nature compared to plant sterols. This was evidenced by using gas liquid chromatography to evaluate phytosterol contents in vegetables commonly consumed where pea, cauliflower, broccoli, romaine lettuce, cowpea and scallion had around 50 to $20 \mathrm{mg}$ per $100 \mathrm{~g}$ of edible piece (Han et al., 2008). In addition to vegetables, microalgae have been considered as a great source of PS (Le Goff et al., 2019).

\section{ENTEROCYTE UPTAKE AND BLOOD ABSORPTION}

PS, as well as cholesterol, are quickly uptaken by the enterocyte (Igel et al., 2003). Due to its structural similarity to cholesterol, PS can be uptaken by enterocytes through the NiemannPick C1-like 1 (NPC1L1) multi-pass transporter (Hu et al., 2021). Between these two types of molecules, plant sterol is better absorbed than stanol (Igel et al., 2003), suggesting that their chemical structure play an important role. Unesterified cholesterol also utilizes the NPC1L1 transporter to cross the plasma membrane of the intestinal cell. Thus, ingested PS compete with cholesterol to enter the intestinal cell. As a consequence, this absorption displacement causes unesterified cholesterol to pass to the colon for excretion. Then, a high concentration of PS in the diet reduces cholesterol absorption. In fact, a clinical assay showed that PS reduced the blood absorption of cholesterol present in a meal (Amiot et al., 2013).

Inside the enterocyte, cholesterol is esterified by acyl CoA:cholesterol acyltransferase 2 (ACAT2) to direct its exit via chylomicron towards the bloodstream. On the contrary, chemical differences in PS compared to cholesterol interfere with ACAT2 esterification, increasing their intracellular accumulation which in turn activates the plasma membrane transporters ABCG5 and ABCG8 that pumps out unesterified cholesterol and PS back to the intestinal lumen (Nguyen et al., 2012). Normally, almost all PS are then eliminated from the enterocyte. However, when there is no correct functioning 
of ABCG5/ABCG8 transporters, PS are found in high levels present in blood, a condition termed sitosterolemia (Othman et al., 2013). This condition also points to the fact that PS can be incorporated as part of lipoproteins in the blood. It has been demonstrated, in mice, that plant sterols, but not stanols, are absorbed towards the blood (Igel et al., 2003).

In addition to preventing cholesterol absorption, PS may perturb cholesterol, absorption by other mechanisms. Thus, a 2-week ad-libitum diet of cholesterol plus $\beta$-sitosterol prevented the mRNA upregulation of NPC1L1 in small intestine cells in hamsters (Liu et al., 2015), explaining how PS could reduce hypercholesterolemia.

Most of the PS in edible plants are present in the esterified form (Wang et al., 2018). Therefore, to be uptaken by enterocyte, esterified PS has to be digested to free PS in the same way as diet esterified cholesterol is processed, by the action of cholesterol esterase in the small intestine. In vitro, it has been shown that pancreatic cholesterol esterase is able to hydrolyze esterified plant sterol and stanol suggesting that this process could happen in vivo to ensure plant sterol absorption (Brown et al., 2010).

PS level in blood in healthy subjects has been reported. The ingestion of PS in adults with a strict plant-based diet is around $500 \mathrm{mg} \mathrm{a}$ day and the ratio $\beta$-sitosterol/cholesterol is significantly higher in them compared to nonvegetarian subjects (Jaceldo-Siegl et al., 2017). Therefore, the amount of PS in the diet (over that of cholesterol) promotes the blood absorption of these plant sterols.

\section{PS AND CARDIOVASCULAR DISEASES}

It has been extensively demonstrated that PS ingestion reduces serum cholesterol and atherogenic lesions in animal models genetically prone to develop atherosclerosis. The supplementation of a mixture of PS reduced the appearance of atheromas in apolipoprotein E-knockout mice by increasing HDL-cholesterol and decreasing hepatic lipase (Moghadasian et al., 1999). In another study, the addition of plant stanols dramatically reduced the extent and severity of atheromas in the apoE*3-Leiden transgenic mice by diminishing VLDL-, IDL- and LDL-cholesterol (Volger et al., 2001).

To further prove the significance of PS in cardiovascular diseases, clinical trials using PS in food have been tested. After a period of 3 weeks ingesting PS containing fat-free milk, healthy subjects reduced their LDL- and nonHDL-cholesterol (San Mauro-Martín et al., 2016). Recently, a clinical study in Brazil showed that regular consumption of phytosterols (>390 mg/ day) was associated with lower total and LDLcholesterol in healthy people, with no changes in markers of subclinical atherosclerosis (Pereira et al., 2021).

However, in some studies, the expected protective effect against dyslipidemia was not observed. In a Brazilian study, administration of PS for 8 weeks to children and adolescents with dyslipidemia did not reduce LDL-cholesterol (Tavares et al., 2021). This difference in results might be a consequence of the genetic variability among the participants in each study or the degree of development of the disease of the subjects.

\section{PS AND CANCER}

A case-control study in Uruguay, hospitalized subjects were interviewed to fill a questionnaire to list their food consumption. It was shown that PS reduced the risk of adenocarcinoma of the lung in men (Mendilaharsu et al., 1998). The same group also showed that PS, among other plant molecules, reduced the risk of breast cancer (Ronco et al., 1999). In a retrospective study, PS consumption was also found to reduce the risk of endometrial cancer among women in western New York (McCann et al., 2000). Also, 
PS ( $\beta$-sitosterol, campesterol and campestanol) were found in an inverse association with colorectal cancer risk within Chinese subjects (Huang et al., 2017)

In vitro studies have confirmed the previous epidemiological results. Thus, $\beta$-sitosterol promotes the expression and activates the extrinsic death receptor FAS signaling in breast cancer cells (Awad et al., 2007). In another study, $\gamma$-sitosterol induced G2/M arrest in MCF7 and A549 human cancer cells (Sundarraj et al., 2012). Another PS, campesterol, was shown to inhibit proliferation and cell cycle progression of ovarian cancer cells (Bae et al., 2021). In the same manner, stigmasterol was observed to inhibit cell migration and induce G2/M cell cycle arrest in human gastric cancer cell lines ( $\mathrm{Li}$ et al., 2018).

\section{CONCERNS OF PS IN DIET}

Normally, cholesterol and fatty acids in a meal contribute to the uptake of lipophilic vitamins by enterocytes. Therefore, there is a concern that PS may reduce the absorption of lipid soluble vitamins. In vitro, this assumption was tested using the colon adenocarcinoma Caco-2 cells (Fahy et al., 2004) where $\beta$-sitosterol interfered with $\beta$-carotene uptake by these colon cells. If a diet rich in PS is followed, it is recommended that at least one fruit or vegetable high in $\beta$-carotene (such as carrot, pumpkin, squash, broccoli, spinach, apricot, mango or rock melon) is eaten daily. In general, to avoid this problem a diet rich in fruit, vegetables and unsaturatedcontaining foods should improve the absorption of fat soluble vitamins.

To be highlighted, there are recent studies supporting the idea that PS could be proatherogenic. In a case-control study, high levels of PS:cholesterol in women were associated with increased cardiovascular risk (Rajaratnam et al., 2000). In men, an increased risk of major coronary events was determined due to a high sitosterol/cholesterol ratio (Assmann et al., 2006).

On the other hand, some studies have failed to demonstrate an association of PS consumption and cardiovascular disease (Pinedo et al., 2007;
Windler et al., 2009).

Therefore, PS consumption may decrease cardiovascular disease associated with high blood cholesterol. However, a close evaluation of PS-treated subjects is recommended since the PS treatment may not be effective or could cause major problems. This might be due to genetic background differences.

\section{CONCLUSIONS}

There is abundant evidence to consider PS, as a food component or supplements, for alleviating cardiovascular problems (mainly regulating cholesterol levels) and inhibiting cancer progression. However, a medical follow-up is recommended to avoid possible side effects such as increasing the risk of atherosclerosis.

\section{ACKNOWLEDGMENTS}

F. Ma was supported by the Central Publicinterest Scientific Institution Basal Research Fund for the Chinese Academy of Tropical Agricultural Sciences (No. 1630092019002).

\section{BIBLIOGRAPHIC REFERENCES}

Amiot, M. J., Knol, D., Cardinault, N., Nowicki, M., Bott, R., Antona, C., Borel, P., Bernard, J.-P., Duchateau, G., \& Lairon, D. (2013). Comparable reduction in cholesterol absorption after two different ways of phytosterol administration in humans. European Journal of Nutrition, 52(3), 12151222. https://doi.org/10.1007/s00394-0120432-3

Assmann, G., Cullen, P., Erbey, J., Ramey, D. R., Kannenberg, F., \& Schulte, H. (2006). Plasma sitosterol elevations are associated with an increased incidence of coronary events in men: Results of a nested casecontrol analysis of the Prospective Cardiovascular Münster (PROCAM) study. Nutrition, Metabolism, and Cardiovascular Diseases: NMCD, 16(1), 13-21. https://doi. org/10.1016/j.numecd.2005.04.001

Awad, A. B., Chinnam, M., Fink, C. S., \& Bradford, P. G. (2007). Beta-Sitosterol activates Fas signaling in human breast cancer cells. Phytomedicine: International Journal of 
Phytotherapy and Phytopharmacology, 14(11), 747-754. https://doi.org/10.1016/j. phymed.2007.01.003

Bae, H., Park, S., Yang, C., Song, G., \& Lim, W. (2021).Disruption ofEndoplasmic Reticulum and ROS Production in Human Ovarian Cancer by Campesterol. Antioxidants (Basel, Switzerland), 10(3), 379. https://doi. org/10.3390/antiox10030379

Brown, A. W., Hang, J., Dussault, P. H., \& Carr, T.P. (2010). Plant sterol and stanol substrate specificity of pancreatic cholesterol esterase. The Journal of Nutritional Biochemistry, 21(8), 736-740. https://doi. org/10.1016/j.jnutbio.2009.04.008

Cabianca, A., Müller, L., Pawlowski, K., \& Dahlin, P. (2021). Changes in the Plant $\beta$-Sitosterol/ Stigmasterol Ratio Caused by the Plant Parasitic Nematode Meloidogyne incognita. Plants (Basel, Switzerland), 10(2), 292. https://doi.org/10.3390/plants10020292

Clouse, S. D. (2002). Arabidopsis mutants reveal multiple roles for sterols in plant development. The Plant Cell, 14(9), 19952000. https://doi.org/10.1105/tpc.140930

Fahy, D. M., O'Callaghan, Y. C., \& O'Brien, N. M. (2004). Phytosterols: Lack of cytotoxicity but interference with beta-carotene uptake in Caco-2 cells in culture. Food Additives and Contaminants, 21(1), 42-51. https://doi. org/10.1080/02652030310001636921

Han, J.-H., Yang, Y.-X., \& Feng, M.-Y. (2008). Contents of Phytosterols in Vegetables and Fruits Commonly consumed in China. Biomedical and Environmental Sciences, 21(6), 449-453. https://doi.org/10.1016/ S0895-3988(09)60001-5

Hu, M., Yang, F., Huang, Y., You, X., Liu, D., Sun, S., \& Sui, S.-F. (2021). Structural insights into the mechanism of human NPC1L1mediated cholesterol uptake. Science Advances, 7(29), eabg3188. https://doi. org/10.1126/sciadv.abg3188
Huang, J., Xu, M., Fang, Y.-J., Lu, M.-S., Pan, Z.-Z., Huang, W.-Q., Chen, Y.-M., \& Zhang, C.-X. (2017). Association between phytosterol intake and colorectal cancer risk: A casecontrol study. The British Journal of Nutrition, 117(6), 839-850. https://doi. org/10.1017/S0007114517000617

Igel, M., Giesa, U., Lutjohann, D., \& von Bergmann, K. (2003). Comparison of the intestinal uptake of cholesterol, plant sterols, and stanols in mice. Journal of Lipid Research, 44(3), 533-538. https://doi.org/10.1194/jlr. M200393-JLR200

Jaceldo-Siegl, K., Lütjohann, D., Sirirat, R., Mashchak, A., Fraser, G. E., \& Haddad, E. (2017). Variations in dietary intake and plasma concentrations of plant sterols across plant-based diets among North American adults. Molecular Nutrition \& Food Research, 61(8). https://doi.org/10.1002/ mnfr.201600828

Le Goff, M., Le Ferrec, E., Mayer, C., Mimouni, V., Lagadic-Gossmann, D., Schoefs, B., \& Ulmann, L. (2019). Microalgal carotenoids and phytosterols regulate biochemical mechanisms involved in human health and disease prevention. Biochimie, 167, 106-118. https://doi.org/10.1016/j. biochi.2019.09.012

Li, K., Yuan, D., Yan, R., Meng, L., Zhang, Y., \& Zhu, K. (2018). Stigmasterol exhibits potent antitumor effects in human gastric cancer cells mediated via inhibition of cell migration, cell cycle arrest, mitochondrial mediated apoptosis and inhibition of JAK/STAT signalling pathway. Journal of B.U.ON.: Official Journal of the Balkan Union of Oncology, 23(5), 1420-1425.

Liu, Y., Lei, L., Wang, X., Ma, K. Y., Li, Y. M., Wang, L., Man, S. W., Huang, Y., \& Chen, Z.Y. (2015). Plasma cholesterol-raising potency of dietary free cholesterol versus cholesteryl ester and effect of $\beta$-sitosterol. Food Chemistry, 169, 277-282. https://doi. org/10.1016/j.foodchem.2014.07.123 
McCann, S. E., Freudenheim, J. L., Marshall, J. R., Brasure, J. R., Swanson, M. K., \& Graham, S. (2000). Diet in the epidemiology of endometrial cancer in western New York (United States). Cancer Causes \& Control: CCC, 11(10), 965-974. https://doi. org/10.1023/a:1026551309873

Mendilaharsu, M., De Stefani, E., DeneoPellegrini, H., Carzoglio, J., \& Ronco, A. (1998). Phytosterols and risk of lung cancer: A case-control study in Uruguay. Lung Cancer (Amsterdam, Netherlands), 21(1), 37-45. https://doi.org/10.1016/ s0169-5002(98)00044-0

Moghadasian, M. H., McManus, B. M., Godin, D. V., Rodrigues, B., \& Frohlich, J. J. (1999). Proatherogenic and antiatherogenic effects of probucol and phytosterols in apolipoprotein E-deficient mice: Possible mechanisms of action. Circulation, 99(13), 1733-1739. https://doi.org/10.1161/01. cir.99.13.1733

Nguyen, T. M., Sawyer, J. K., Kelley, K. L., Davis, M. A., Kent, C. R., \& Rudel, L. L. (2012). ACAT2 and ABCG5/G8 are both required for efficient cholesterol absorption in mice: Evidence from thoracic lymph duct cannulation. Journal of Lipid Research, 53(8), 1598-1609. https://doi.org/10.1194/ jlr.M026823

Oh, M.-J., So, H.-J., Hong, E.-S., Shin, J.-A., \& Lee, K.-T. (2021). Presence of Cholesterol in Non-Animal Organisms: Identification and Quantification of Cholesterol in Crude Seed Oil from Perilla frutescens and Dehydrated Pyropia tenera. Molecules (Basel, Switzerland), 26(12), 3767. https:// doi.org/10.3390/molecules26123767

Othman, R. A., Myrie, S. B., \& Jones, P. J. H.

(2013). Non-cholesterol sterols and cholesterol metabolism in sitosterolemia. Atherosclerosis, 231(2), 291-299. https://doi. org/10.1016/j.atherosclerosis.2013.09.038

Pereira, T. S., Fonseca, F. A. H., Fonseca, M. I. H., Martins, C. M., Fonseca, H. A. R., Fonzar,
W. T., Goulart, A. C., Bensenor, I. M., Lotufo, P. A., \& Izar, M. C. (2021). Phytosterol consumption and markers of subclinical atherosclerosis: Cross-sectional results from ELSA-Brasil. Nutrition, Metabolism, and Cardiovascular Diseases: NMCD, 31(6), 1756-1766. https://doi.org/10.1016/j. numecd.2021.02.031

Pinedo, S., Vissers, M. N., von Bergmann, K., Elharchaoui, K., Lütjohann, D., Luben, R., Wareham, N. J., Kastelein, J. J. P., Khaw, K.-T., \& Boekholdt, S. M. (2007). Plasma levels of plant sterols and the risk of coronary artery disease: The prospective EPIC-Norfolk Population Study. Journal of Lipid Research, 48(1), 139-144. https://doi. org/10.1194/jlr.M600371-JLR200

Rajaratnam, R. A., Gylling, H., \& Miettinen, T. A. (2000). Independent association of serum squalene and noncholesterol sterols with coronary artery disease in postmenopausal women. Journal of the American College of Cardiology, 35(5), 1185-1191. https://doi. org/10.1016/s0735-1097(00)00527-1

Ronco, A., De Stefani, E., Boffetta, P., DeneoPellegrini, $H_{.}, \quad$ Mendilaharsu, M., \& Leborgne, F. (1999). Vegetables, fruits, and related nutrients and risk of breast cancer: A case-control study in Uruguay. Nutrition and Cancer, 35(2), 111-119. https://doi. org/10.1207/S15327914NC352_3

San Mauro-Martín, I., Collado-Yurrita, L. Blumenfeld-Olivares, J. A., CuadradoCenzual, M. Á., Calle-Purón, M. E., Hernández-Cabria, M., Garicano-Vilar, E., Pérez-Arruche, E., Arce-Delgado, E., \& CiudadCabañas, M. J. (2016). Efecto de esteroles vegetales en la reducción del colesterol plasmático: Ensayo clínico, controlado, aleatorizado, cruzado y doble ciego. Nutricion Hospitalaria, 33(3), 279. https://doi.org/10.20960/nh.279

Sonawane, P. D., Pollier, J., Panda, S., Szymanski, J., Massalha, H., Yona, M., Unger, T., Malitsky, S., Arendt, P., Pauwels, L., Almekias-Siegl, E., Rogachev, I., Meir, S., Cárdenas, P. D., 
Masri, A., Petrikov, M., Schaller, H., Schaffer, A. A., Kamble, A., ... Aharoni, A. (2016). Plant cholesterol biosynthetic pathway overlaps with phytosterol metabolism. Nature Plants, 3, 16205. https://doi.org/10.1038/ nplants.2016.205

Sundarraj, S., Thangam, R., Sreevani, V., Kaveri, K., Gunasekaran, P., Achiraman, S., \& Kannan, S. (2012). $\gamma$-Sitosterol from Acacia nilotica $L$. induces $G 2 / M$ cell cycle arrest and apoptosis through c-Myc suppression in MCF-7 and A549 cells. Journal of Ethnopharmacology, 141(3), 803-809. https://doi.org/10.1016/j.jep.2012.03.014

Tavares, A. K. M. M., Ribas, S. A., Paravidino, V. B., Sgambato, M. R., Rodrigues, R. da R. M., da Rocha, C. M. M., Sichieri, R., \& Cunha, D. B. (2021). Effect of phytosterol capsule supplementation associated with the National Cholesterol Education Program Step 2 diet on low-density lipoprotein in children and adolescents with dyslipidemia: A double-blind crossover trial. Nutrition (Burbank, Los Angeles County, Calif.), 82, 111051. https://doi.org/10.1016/j. nut.2020.111051

Volger, O. L., Mensink, R. P., Plat, J., Hornstra, G., Havekes, L. M., \& Princen, H. M. (2001). Dietary vegetable oil and wood derived plant stanol esters reduce atherosclerotic lesion size and severity in apoE*3-Leiden transgenic mice. Atherosclerosis, 157(2), 375-381. https://doi.org/10.1016/s00219150(00)00750-4

Wang, M., Huang, W., Hu, Y., Zhang, L., Shao, Y., Wang, M., Zhang, F., Zhao, Z., Mei, X., Li, T., Wang, D., Liang, Y., Li, J., Huang, Y., Zhang, L., Xu, T., Song, H., Zhong, Y., \& Lu, B. (2018). Phytosterol Profiles of Common Foods and Estimated Natural Intake of Different Structures and Forms in China. Journal of Agricultural and Food Chemistry, 66(11), 2669-2676. https://doi.org/10.1021/acs. jafc.7b05009

Windler, E., Zyriax, B.-C., Kuipers, F., Linseisen, J., \& Boeing, H. (2009). Association of plasma phytosterol concentrations with incident coronary heart disease Data from the CORA study, a case-control study of coronary artery disease in women. Atherosclerosis, 203(1), 284-290. https://doi.org/10.1016/j. atherosclerosis.2008.06.014

Zhang, X., Lin, K., \& Li, Y. (2020). Highlights to phytosterols accumulation and equilibrium in plants: Biosynthetic pathway and feedback regulation. Plant Physiology and Biochemistry: PPB, 155, 637-649. https:// doi.org/10.1016/j.plaphy.2020.08.021 